\title{
Pembelajaran Matematika dengan ICTSebagai Sarana Pengembangan Kecerdasan Emosional Siswa Menuju Pembangunan Karakter Bangsa
}

\author{
Ibrahim \\ Program Studi Pendidikan Matematika, Fakultas Sains dan Teknologi, UIN Sunan Kalijaga, \\ Jl. Marsda Adisucipto No. 1 Yogyakarta 55281, Indonesia
}

Korespondensi; Email: ibrahim311079@live.com

\begin{abstract}
Abstrak
Saat ini ICT meningkat pesat, walaupun sebenarnya kualitas pengajaran matematika masih dalam aspek kognitif sambil melupakan aspek non kognitif. Pengabaian aspek afektif serta kecerdasan emosional dalam pengajaran matematika berkontribusi pada situasi sosial yang menghambat pengembangan karakter nasional. Jadi, pengembangan ICT harus lebih disukai sebagai alternatif pengajaran matematika untuk memperluas kecerdasan emosional terhadap pengembangan karakter nasional. Karena alasan bahwa karena perkembangan TIK memiliki sisi lain yang cenderung meningkatkan keterampilan emosional dalam kehidupan sosial.
\end{abstract}

Kata Kunci: Instruksi matematika; ICT; Kecerdasan emosional; Karakter bangsa

\begin{abstract}
Nowadays ICT is rising rapidly, although in fact the effort of mathematics teaching quality is still concerning in cognitive aspect while forgetting non-cognitive aspect. The neglect of affective aspect as well emotional quotient in mathematics teaching contributes to social situation that hamper national character development. So, the development of ICT must be preferred as an alternative for mathematics teaching in order to extend emotional quotient towards national character development. It stands to reason that due to the development of ICT has another side that is likely to increase emotional skills in social life.
\end{abstract}

Keywords: Mathematics instruction; ICT; Emotional intelligence; Character of the nation

\section{Pendahuluan}

Peran dari matematika dalam kemajuan dan kemunduran umat manusia, Levvit (Buchori, 2000) menyatakan bahwa jika suatu masyarakat dibiarkan dalam kebutaan matematika maka akan membuat masyarakat tersebut kehilangan kemampuan untuk berpikir secara disipliner dalam menghadapi masalah-masalah nyata, dari masalah-masalah yang relatif sepele hingga masalah-masalah yang benar-benar rumit. Hal ini memperlihatkan betapa pentingnya pembelajaran matematika bagi suatu masyarakat terlebih bagi masyarakat Indonesia, khususnya bagi generasi yang akan datang sangat penting dan perlu terus-menerus ditingkatkan. Dalam hal ini yang berkaitan langsung dengan pembelajaran matematika, yaitu dunia pendidikan dan lebih khususnya lagi pendidikan matematika di sekolah, mulai dari sekolah dasar hingga perguruan tinggi.

Namun demikian, dalam meningkatkan proses pembelajaran matematika, terkesan yang menjadi perhatian adalah aspek kognitif saja. Dengan kata lain, terkesan untuk aspek non-kognitif dilupakan begitu saja. Hal ini diyakini berdasarkan pengalaman penulis selama sepuluh tahun terakhir melalui pengamatan langsung terhadap praktek pembelajaran di kelas serta wawancara dengan pengajar bidang studi matematika mulai dari tingkat sekolah dasar sampai perguruan tinggi. Padahal, banyak bukti memperlihatkan bahwa tidak cukup bagi seseorang hanya jika memiliki kemampuan kognitif saja untuk dapat bahagia dan berhasil dalam kehidupan (Goleman, 1996). Bahkan, banyak orang 
yang kemampuan kognitifnya baik ternyata malah menjadi batu sandungan bagi lingkungan sekitarnya (Martin, 2003).

Pengabaian pada hal-hal yang berkaitan dengan aspek afektif dalam pembelajaran matematika di kelas, berpeluang memberikan sumbangan pada situasi sosial yang terjadi belakangan ini yang semakin menghawatirkan. Hal ini cukup beralasan, karena ada berbagai peristiwa dalam pendidikan yang semakin merendahkan harkat dan martabat manusia serta menjauhkan dari proses pembangunan karakter bangsa yang kuat. Hancurnya nilai-nilai moral dan karakter bangsa ditandai dengan adanya indikasi, seperti: merebaknya ketidakadilan, tipisnya rasa solidaritas, cepat putus asa atau daya juang yang rendah, berusaha mendapatkan jalan pintas, ketidakjujuran, dan lain sebagainya telah terjadi dalam lembaga pendidikan kita. Hal ini mewajibkan para pendidik matematika untuk mempertanyakan sejauh mana telah mampu menjawab dan tanggap atas berbagai macam persoalan dalam masyarakat kita, mengingat dan mempertimbangkan tujuan adanya mata pelajaran matematika di sekolah?

Pendidik matematika, dalam membimbing pembelajaran matematika di kelas sudah semestinya memperhatikan aspek non-kognitif di samping kemampuan-kemampuan yang termasuk dalam aspek kognitif, sebagai upaya memperbaiki persoalan kehidupan saat ini dan masa yang akan datang. Aspek non-kognitif yang urgen dan esensi dalam memperbaiki moral dan karakter bangsa salah satunya yaitu kecerdasan emosional (emotional intelligence).

Faktor emotional intelligence (EI) belakangan ini telah diakui oleh para psikolog sebagai salah satu faktor penentu kesuksesan seseorang dalam berbagai aspek kehidupannya. Demikian pentingnya faktor emotional intelligence ini, sehingga di Amerika Serikat telah didirikan Sekolah Perasaan (Shapiro, 2003). Sekolah ini sangat diminati oleh sebagian besar masyarakat yang puteraputerinya memiliki ketidakberesan pribadi. Selain itu, Shapiro (2003) menegaskan bahwa sudah banyak penelitian di akhir abad ke-20 yang menunjukkan El dan keterampilan sosial sebagai pembangun karakter yang lebih penting bagi keberhasilan anak dibandingkan kecerdasan kognitif yang diukur melalui IQ. Beberapa pandangan dan temuan yang diperoleh Stein dan Book, 2000; Hammer, 1996; Senge, 1990; Salamon, 1993; Rosenthal, 1997; Hammond, 1996, Cooper dan Sawaf, 2001; Dryden dan Vos, 2000; Goleman,1996; dan Kotulak,1996; memperlihatkan betapa pentingnya El terhadap berbagai aspek kehidupan manusia, salah satu di antaranya adalah aspek keberhasilan belajar seseorang (Cooper dan Sawaf, 2000; Stein dan Book, 2000; Dryden dan Vos, 2000; Goleman, 2000). Menariknya dari hasil penelitian-penelitian tersebut bahwa El tidak seperti IQ yang cenderung tetap, El dapat diajarkan dan dilatihkan serta dapat meningkat atau menurun pada setiap tahap perkembangan anak.

Beberapa fakta yang telah menjadi data, mengemukakan bahwa telah terjadi penurunan kecerdasan emosional dikalangan siswa-siswa Indonesia seiring dengan peningkatan kecerdasan intelektual (Martin, 2003; Puspasari, 2009). Sementara itu, Daniel Goleman adalah seorang pakar kecerdasan emosional menyatakan bahwa studinya di tahun 1970-an dan 1980-an menunjukkan bahwa penurunan kecerdasan emosional terjadi pada anak-anak Amerika di tengah perkembangan Information and Communication Technologi (ICT dan selanjutnya juga ditulis ICT) yang pesat sebagai buah dari nalar manusia. Kemudian, beberapa ahli psikologi terkemuka mengemukakan hasil temuan penelitiannya bahwa tidak sedikit siswa yang cerdas secara intelektual mengalami kesulitan dalam berhubungan dengan siswa lain, diasingkan oleh temannya, dan akhirnya mengalami ketidaksuksesan dalam sekolahnya (Segal, 1997; Puspasari, 2009). Hal ini memberikan inspirasi atau sinyal pada para pendidik untuk terus melakukan proses pengembangan pendefinisian awal atau pendefinisian ulang terhadap kecerdasan intelektual. Kecerdasan intelektual ini biasanya diidentikan dengan kemampuan-kemampuan yang besifat kognitif.

Temuan-temuan dari para pakar biopsikologi mengemukakan bahwa emosional seseorang membantu untuk memfokuskan logika dan akal sehatnya. Mengintegrasikan emosi dan intelektual akan memberikan performa optimal dan tindakan pengambilan keputusan yang baik (Jensen, 2008). Hal ini memberikan implikasi pada pembelajaran bahwa kondisi emosional siswa harus dianggap sama pentingnya dengan konten kognitif intelektual dari materi ajarnya. Oleh karena itu, pembelajaran matematika harus dapat dikelola sedemikian hingga mampu mewujudkan intelektual dan emosional yang seimbang. Harapan ini akan dicapai manakala potensi kognitif siswa difungsikan secara optimal dengan dibarengi kecerdasan emosional yang tinggi pula. 
Sementara itu, untuk menciptakan proses pembelajaran matematika dengan penggunaan potensi siswa secara optimal, Sunandar (2008) menyatakan bahwa kecerdasan emosional yang dimiliki siswa perlu menjadi perhatian. Hal ini didukung oleh hasil penelitian Sunandar dan Darwis bahwa secara umum siswa yang kecerdasan emosionalnya tinggi lebih baik hasil belajar matematikanya jika dibandingkan dengan siswa yang kecerdasan emosionalnya rendah (Sunandar, 2008; Darwis, 2007)

Fakta-fakta yang telah diungkapkan di atas, memberikan petunjuk untuk segera memperbaiki kelemahan-kelamahan dari proses pembelajaran matematika di kelas yang berkaitan aspek nonkognitif, yaitu kecerdasan emosional siswa, di samping aspek kognitif siswa. Karena, aspek kognitif dan non-kognitif tersebut diharapkan juga menjadi kompetensi dasar dalam pembelajaran matematika berdasarkan kurikulum yang berlaku saat ini, yaitu KTSP, hingga akhirnya kompetensi tersebut dapat membangun karakter bangsa yang kuat.

Perkembangan ICT yang pesat seperti saat ini, tampaknya sulit untuk mengabaikan potensi ICT dalam memajukan pembelajaran matematika, meskipun tidak sedikit yang masih beranggapan bahwa penggunaannya akan berdampak pada pengabaian pada aspek emosional siswa. Namun, ternyata anggapan yang pesimis terhadap penggunaan ICT dalam pembelajaran justru tidak banyak didukung oleh beberapa hasil riset yang telah dilakukan. Beberapa penelitian terkait penggunaan ICT justru menunjukkan bahwa penggunaannya telah memacu kekuatan-kekuatan kecerdasan emosional (Shapiro, 2003; Muijs dan Reynolds, 2008). Telah menjadi pengetahuan umum bahwa ICT lahir dan berkembang salah satunya berpijak pada prinsip-prinsip, aturan-aturan, atau teorema-teorema yang ada pada matematika. Oleh karena itu, pembelajaran matematika dengan ICT sangat mungkin untuk dilakukan. Lebih jauh, pembelajaran matematika dengan ICT memiliki kemungkinan untuk dapat dijadikan sebagai alternatif sarana dalam mengembangkan kecerdasan emosional yang menuju pada usaha membangun karakter bangsa.

Uraian di atas memunculkan pertanyaan yang perlu dijawab, yaitu bagaimana pembelajaran matematika dengan ICT dapat menjadi sarana mengembangan kecerdasan emosional menuju pada membangun karakter bangsa? Jawaban atas pertanyaan ini tentu perlu pendalaman lebih lanjut. Untuk itu, pada bagian selanjutnya penulis akan mencoba menguraikannya, kemudian mencoba untuk menarik simpulan.

\section{Pembahasan}

Berbeda dengan inovasi pembelajaran lainnya, inovasi penggunaan ICT pada pembelajaran matematika yang dilaporkan dalam beberapa hasil penelitian dapat dikatakan memiliki dampak yang positif terhadap hasil belajar siswa. Shapiro (2003) mengungkapkan beberapa temuan penelitian bahwa penggunaan ICT (seperti software multimedia dan internet) dalam pembelajaran ternyata tidak menjadikan siswa terisolasi, justru dapat mengajarkan berbagai keterampilan sosial kepada siswa. Meskipun temuan hasil Penelitian yang diungkap Shapiro tersebut tidak menyebutkan penggunaan software multimedia dan internet dalam pembelajaran matematika, akan tetapi hal ini memberikan sinyal yang baik untuk dilakukan secara khusus pada pembelajaran matematika.

Lebih jauh, penggunaan ICT seperti software multimedia dan internet dalam pembelajaran matematika sangat mungkin untuk dijadikan sarana pengembangan kecerdasan emosional siswa menuju pembangunan karakter bangsa. Hal ini, dikarenakan menurut Shapiro (2003) penggunaan ICT seperti software multimedia dan internet memenuhi semua persyaratan untuk melatih dan mengembangkan kecerdasan emosional.

Bagaimana pembelajaran matematika dengan ICT dapat menjadi sarana pengembangan kecerdasan emosional siswa menuju pembangunan karakter bangsa? Berikut ini uraian yang dapat dijadikan jawaban pertanyaan tersebut.

Menurut Becker (Almeqdadi, 2005) penggunaan ICT seperti halnya komputer dapat dimanfaatkan untuk mengatasi perbedaan invidual dan menstimulir belajar siswa. Siswa dapat mengatur kecepatan belajarnya, disesuaikan dengan tingkat kemampuannya. Bagi para siswa yang sulit mengikuti pembelajaran matematika (slow learner), mereka dapat mengulang beberapa kali sampai benar-benar menguasai materi yang harus dipahaminya. Sedangkan, bagi siswa yang kemampuannya tinggi (fast learner), mereka dapat diberi pengayaan (enrichment) sehingga mereka akan merasa lebih tertantang 
dan mendapat kesempatan untuk melakukan eksplorasi konsep secara lebih mendalam. Dengan demikian, siswa merasa kesulitan belajarnya dapat diatasi, sehingga mereka akan merasa nyaman atau tidak dalam keadaan cemas yang berlebihan pada proses pembelajaran. Di sinilah, sesungguhnya siswa dilatih untuk mengenal emosional diri serta mengelolanya. Sementara di sisi lain, sesungguhnya dalam kondisi pembelajaran matematika semacam ini siswa dapat memotivasi diri dengan baik untuk menggali potensinya, karena mereka merasa difasilitasi.

Penggunaan ICT seperti halnya internet akan mempermudah berkomunikasi antara siswa dan siswa, siswa dan guru, atau siswa dan orang dewasa lain selain guru tanpa dibatasi oleh halhal yang protokoler. Komunikasi awal yang biasanya dirasakan sulit oleh siswa ketika akan meminta bantuan pada siswa lain atau guru dalam menyelesaikan masalah matematis yang dihadapinya, menjadi lebih mudah karena mereka dapat menyembunyikan ekspresi wajah ketika berkomunikasi. Namun demikian, dengan diawali komunikasi melalui internet, selanjutnya komunikasi siswa dan siswa atau siswa dan guru secara langsung dapat berjalan lancar karena mereka sudah saling mengenal satu sama lain. Selain itu, saling bertukar ide, gagasan, dan informasi serta saling mengkritisi sangat mungkin untuk dapat dilakukan melalui internet, misalnya di dalam chat group, e-mail, media sosial, dan blog.

Penggunaan komunitas online semakin populer, sehingga ketika siswa menyajikan penyelesaian soal matematika maka langsung menerima umpan balik tentang kebenaran dari penyelesaiannya. Penggunaan ICT dalam pembelajaran matematika dapat memperbesar peluang siswa untuk belajar jarak-jauh dengan para ahli matematika, dan dapat dimanfaatkan sebagai nara sumber dalam mengerjakan pekerjaan-rumah (PR). Penggunaan lebih jauh ICT pada pembelajaran matematika adalah memungkinkan siswa untuk melanjutkan pembelajaran dari sekolah ke rumah. Saat ini banyak software yang dapat digunakan untuk menyimpan bahan ajar, setoran penyelesaian PR, dan latihan soal pada situs-situs yang dapat diakses dengan mudah oleh siswa. Keunggulannya, apabila siswa menyajikan atau meyetorkan PR, mereka dapat langsung menerima umpan balik atas hasilnya, karena latihan-latihan soal tersebut dapat dinilai oleh program software atau pihak guru yang kebetulan sedang online.

Penggunaan ICT dalam pembelajaran matematika telah memberikan kesempatan yang luas pada siswa untuk: berinteraksi sehingga saling mengenal dan membina hubungan antara siswa dan siswa, siswa dan guru, atau siswa dan orang dewasa selain guru. Menurut Muijs dan Reynolds (2008) interaktivitas semacam ini berpeluang besar untuk dapat memotivasi siswa dalam belajar. Berdasarkan beberapa penelitian tentang motivasi dalam pembelajaran bahwa motivasi yang tinggi berpengaruh terhadap usaha keras siswa dalam mencapai prestasi belajarnya.

Apabila merujuk pada rumusan Goleman (1996) tentang kecerdasan emosional maka dapat dikatakan kecerdasan emosional siswa berpeluang besar untuk dapat dikembangkan melalui pembelajaran matematika dengan ICT. Hal ini, dikarenakan sebagaimana pada uraian sebelumnya bahwa dalam pembelajaran matematika dengan ICT siswa memiliki kesempatan luas untuk memotivasi diri, melatih mengenal dan mengelola emosi diri, mengenal orang lain, serta membina hubungan dengan orang lain. Semua dimensi yang memiliki kesempatan luas untuk dilatihkan tersebut merupakan dimensi-dimensi dari kecerdasan emosional siswa yang dirumuskan oleh Goleman.

\section{Kesimpulan}

Menurut Goleman (1996), kecerdasan intelektual (IQ) hanya menyumbang 20\% bagi kesuksesan, sedangkan $80 \%$ adalah sumbangan faktor kekuatan-kekuatan lain, di antaranya adalah kecerdasan emosional atau Emotional Intellegence (EI). Sementara itu, Shapiro (2003) menegaskan bahwa sudah banyak penelitian di akhir abad ke-20 yang menunjukkan El sebagai pembangun karakter yang lebih penting bagi keberhasilan anak dibandingkan kecerdasan kognitif yang diukur melalui IQ. Hal ini artinya, proses memperbaiki atau meningkatkan kecerdasan emosional siswa pada pembelajaran dapat dijadikan cikal bakal dalam membangun karakter bangsa, tidak terkecuali pada pembelajaran matematika. Kemudian, sebagaimana telah diuraikan pada bagian sebelumnya, kecerdasan emosional 
siswa berpeluang besar untuk dapat dikembangkan melalui pembelajaran matematika dengan ICT. Dengan demikian, pembelajaran matematika dengan ICT dapat dijadikan sebagai alternatif sarana untuk mengembangkan kecerdasan emosional menuju pembangunan karakter bangsa.

\section{Referensi}

[1] Almeqdadi. 2005. The effect of using the Geometers Sketchpad (GSP )on Jordanian students understanding some geometrical concepts. [online]. Available: www.cimt.plymouth.ac.uk/journal/almeqdadi.pdf [4 Mei 2005].

[2] Cooper, R. K., dan Sawaf, A. 2001. Executive EQ (Kecerdasan Eeosional dalam kepemimpinan dan oganisasi). Jakarta: PT. Gramedia Pustaka Utama.

[3] Darwis, M. 2006. Model pembelajaran matematika dengan mempertimbangkan kecerdasan emosional. Disertasi pada PPS UNESA. Surabaya: Tidak Dipublikasikan.

[4] Depdiknas 2006. Kurikulum tingkat satuan pendidikan. Jakarta: Depdiknas.

[5] Dryden, G. dan Vos, J. 2000. The learning revolution (Revolusi Cara Belajar). Jakarta: PT. Kaifa.

[6] Goleman, D. 1996. Emotional intelligence. Jakarta: Gramedia.

[7] Goleman, D. 2000. Working with emotional intelligence. Jakarta: Gramedia.

[8] Jensen, E. 2008. Brain-base learning. California: Corwin Press.

[9] Martin, D. A. 2003. Emotional quality management. Jakarta: Arga.

[10] Muijs, D. dan Reynolds, D. 2008. Effective teaching. London. Sage Publications.

[11] Puspasari, A. 2009. Emotional intelligent parenting. Jakarta: Elex Media Komputindo.

[12] Segal, J. 1997. Raising your emotional intellegence (Melejitkan kecerdasan emosional). Bandung: Kaifa.

[13] Shapiro, E. L. 2003. Mengajarkan emotional intelligence pada anak. Jakarta: Gramedia.

[14] Stien, J., Steven, B. E., Howard. 2000. The El edge: emotional intellegence and your success (Ledakan El). Bandung: Kaifa

[15] Sunandar. 2008. Pengaruh penilaian portofolio dan kecerdasan emosional terhadap hasil belajar matematika topik dimensi tiga siswa kelas X SMA Negeri 4 Kendari tahun 2006. Dalam Rusgianto, dkk. (ed.). Prosiding seminar nasional nasional matematika dan pendidikan matematika. Yogyakarta: UNY.

[16] Yusof, M. S. (2004). Peranan EQ dalam bidang pendidikan. Dalam Hamid (ed.). Panduan meningkatkan kecerdasan emosi. Kuala Lumpur: Profesional. 